Gut, 1964, 5, 463

\title{
Effect of paracetamol (N-acetyl-p-aminophenol) on gastrointestinal bleeding
}

\author{
KERRY GOULSTON AND ALAN SKYRING \\ From the A.W. Morrow Department of Gastroenterology ${ }^{1}$, \\ Royal Prince Alfred Hospital, Sydney, Australia
}

EDITORIAL SYNOPSIS This paper gives firm scientific proof to the already prevailing view that paracetamol does not cause bleeding from the stomach and is an acceptable alternative to aspirin.

There is now ample evidence that the oral administration of aspirin leads to an increase in faecal blood loss in the majority of normal people. Some investigators (Lange, 1957; Alvarez and Summerskill 1958; Stubbé, Pietersen, and Van Heulen, 1962) have used chemical means of testing for occult blood in faeces, and others (Matsumoto and Grossman, 1959; Watson and Pierson, 1960; Holt, 1960; Scott, Porter, Lewis, and Dixon, 1961; Pierson, Holt, Watson, and Keating, 1961; Leonards, 1962; Wood, Harvey-Smith, and Dixon, 1962) have been able to show increased faecal blood loss in subjects whose erythrocytes had been labelled with $\mathrm{Cr}^{51}$. All agree that approximately $70 \%$ of normal people are susceptible, regardless of the method of study or of the population studied.

Paracetamol ( $\mathrm{N}$-acetyl-p-aminophenol) has been suggested as a satisfactory substitute for aspirin (Batterman and Grossman, 1955; Cornely and Ritter, 1956; Newton and Tanner, 1956) but few workers have studied its effect on gastrointestinal blood loss. For this reason it was proposed to investigate paracetamol in relation to gastrointestinal bleeding using $\mathrm{Cr}^{51}$-labelled erythrocytes.

\section{METHODS AND MATERIALS}

Forty-five hospital in-patients with various diagnoses were studied. Faecal blood loss was estimated by labelling red blood cells with $\mathrm{Cr}^{51}$, an accepted and well-established method (Owen, Bollman, and Grindlay, 1954; Jones, 1958; Cameron, 1960). The modification we used was as follows:

Ten millilitres of venous blood was withdrawn from each patient and placed in a sterile stoppered McCartney bottle containing $4 \mathrm{ml}$. of acid-citrate-dextrose solution. Approximately $200 \mu \mathrm{c}$. of $\mathrm{Cr}^{51}$ as a sterile isotonic solution of sodium chromate in saline was added to the McCartney bottle, and at room temperature the bottle

${ }^{1}$ Supported by the Bushell Trust. was gently shaken by hand for $\mathbf{3 0}$ minutes. One hundred milligrams of ascorbic acid was then added and the solution was gently shaken by hand for a further 15 minutes (Read, 1954; Holt, 1960). At the end of this time, the whole mixture was injected intravenously into the patient. The red cells were not washed because Ebaugh, Emerson, and Ross (1953) have found that 80 to $95 \%$ of the $\mathrm{Cr}^{51}$ becomes bound to the red cells without washing with saline. The collection of faeces was started 36 to 48 hours after injection of the $\mathrm{Cr}^{51}$-labelled red cells and continued for eight consecutive days.

The first three days of the collections served as a control period and for the last five days $4 \mathrm{~g}$. of paracetamol ( $\mathrm{N}$-acetyl-p-aminophenol) tablets was given uncrushed in a dose of $1 \mathrm{~g}$. (two tablets) three times a day half an hour before meals and $1 \mathrm{~g}$. on retiring. In order to compare the effects of paracetamol with aspirin, 10 patients were given uncrushed aspirin tablets in a dose of gr. 10 four times a day, over the next immediate five-day period. Each patient was carefully instructed to collect all faeces passed in disposable quarter-gallon metal paint tins with tight-fitting grooved lids, a separate tin being used for each 24-hour collection. Each tin was brought to a weight of $500 \mathrm{~g}$. by adding tap water and the faeces were then homogenized by continuous agitation of the closed tin on a paint shaker for 20 to 30 minutes (Newell, 1960). Samples of $10 \mathrm{ml}$. of heparinized venous blood were taken midway through the collection periods. The $10 \mathrm{ml}$. sample of whole blood was placed in metal paint tins identical to those used for faecal collections and tap water added to make the total weight up to $500 \mathrm{~g}$. The same blood sample was used as a standard for one week, as we have found, like Bannerman (1957) and Scott, Porter, Lewis, and Dixon (1961), that in subjects who are not haemolysing there is very little loss of radioactivity from the blood except that arising from isotopic decay.

The tins were counted unopened in a specially constructed scintillation counter containing a thalliumactivated sodium iodide crystal of 1 in. diameter coupled to a 1 in. photomultiplier tube. The high voltage for the scintillation counter was derived from an Ekco N 600A ratemeter, the number of counts in 3,000 seconds being recorded on an Ekco N 530F scaler. One microcurie of 
$\mathrm{Cr}^{51}$ when distributed in $500 \mathrm{ml}$. of water gave 3,734 counts per minute (0.0019 counts per emitted gamma). The number of millilitres of whole blood present in each 24-hour faecal collection was calculated by dividing the total activity of the stool collection in counts per second by the activity of the standard whole blood in counts per second per millilitre. Mean daily faecal blood loss over any period was calculated by dividing the sum of the amounts of blood lost in each 24-hour period by the number of days in the period. Counting was carried out immediately after the completion of the collection period, either on the ninth or fourteenth day, all readings being corrected for background radioactivity. It was unnecessary to correct for $\mathrm{Cr}^{51}$ decay as all counting was performed on the same day. The counting time of 3,000 seconds enabled sufficient counts to accrue above background to give a counting error of better than $\pm 8 \%$ (1 S.D.) on both standard and sample.

The major criteria for selecting patients were willingness to take part in the project and ability to use the tins; an effort was made to include a fair sample of in-patients in general medical wards, in particular those who were being investigated for a hypochromic microcytic anaemia. All patients were on a normal hospital diet. We were not concerned if there was already gastrointestinal bleeding since Grossman, Matsumoto, and Lichter (1961) have have shown that in these patients aspirin further increases blood loss. Only two patients complained of nausea or dyspepsia with paracetamol in the dosage used. No other analgesics were used in the period under study in any patient.

One hundred and fifty specimens of faeces were tested for the presence of occult blood with Haematest and Occultest tablets using the method recommended by the manufacturers.

\section{RESULTS}

Twenty-seven patients were not bleeding during the control period and the mean daily faecal blood loss in the control period in these patients was $0.6 \mathrm{ml}$. (S.D. $0.4 \mathrm{ml}$.), rising to $0.8 \mathrm{ml}$. (S.D. $0.9 \mathrm{ml}$.) with paracetamol (Table I). The difference between the means was not significant. Nine of the 27 patients in this group had no obvious gastrointestinal lesion. The mean daily faecal blood loss in these, during the control period, was $0.6 \mathrm{ml}$. (S.D. $0.3 \mathrm{ml}$.). Ten of the 27 patients were given aspirin for a further five days. During aspirin administration the mean daily faecal blood loss rose from $0.7 \mathrm{ml}$. (S.D. $0.4 \mathrm{ml}$.) to $3.3 \mathrm{ml}$. (S.D. $3.3 \mathrm{ml}$.). The increase over the control period was significant $(\mathrm{p}<0.05)$.

The second group consisted of 18 patients who were already bleeding in the control period with a mean daily faecal blood loss of $9 \cdot 1 \mathrm{ml}$. (S.D. 9.8 ml.). With paracetamol administration the mean daily faecal blood loss was $9.0 \mathrm{ml}$. (S.D. $10.8 \mathrm{ml}$. (Table II). This difference was not significant.

The results of the chemical occult blood tests with Haematest and Occultest tablets in 150 specimens of faeces are set out in Table III. The positive results

TABLE I

RESULTS IN 27 PATIENTS NOT BLEEDING DURING CONTROL PERIOD

\begin{tabular}{|c|c|c|c|c|}
\hline \multirow[t]{2}{*}{ Patient } & \multicolumn{3}{|c|}{ Mean Daily Faecal Blood Loss (ml.) } & \multirow[t]{2}{*}{ Diagnosis } \\
\hline & Control Period & Paracetamol & Aspirin & \\
\hline 1 & $1 \cdot 2$ & $1 \cdot 0$ & & Cerebral insufficiency \\
\hline 2 & 0.5 & 0.4 & & Myocardial infarction (on anticoagulants) \\
\hline 3 & 0.5 & $0 \cdot 2$ & $8 \cdot 1$ & Post-gastrectomy syndrome \\
\hline 4 & 0.7 & 0.5 & & Myocarditis \\
\hline 5 & 0.8 & 0.5 & & Gastric erosions \\
\hline 6 & 0.4 & $2 \cdot 4$ & & Chronic gastric ulcer \\
\hline 7 & $0 \cdot 3$ & 0.6 & & Gastric erosions \\
\hline 8 & 0.7 & 0.7 & $1 \cdot 3$ & Chronic gastric ulcer \\
\hline 9 & $0 \cdot 2$ & 0.2 & 0.2 & Myocardial infarction (on anticoagulants) \\
\hline 10 & $1 \cdot 0$ & 0.9 & $4 \cdot \overline{5}$ & Subacute bacterial endocarditis \\
\hline 11 & 0.5 & $0 \cdot 2$ & & Chronic duodenal ulcer \\
\hline 12 & 0.4 & $\mathbf{0 . 3}$ & $1 \cdot 3$ & Myelofibrosis \\
\hline 13 & $1 \cdot 5$ & 0.7 & 1.9 & Rheumatoid arthritis \\
\hline 14 & $\mathbf{0} \cdot \mathbf{3}$ & $0 \cdot 2$ & 0.5 & Gastric erosions \\
\hline 15 & $1 \cdot 3$ & 0.6 & 8.4 & Gastric erosions \\
\hline 16 & 1.6 & 0.1 & & Iron-deficiency anaemia \\
\hline 17 & $0 \cdot 1$ & 0.3 & & Iron-deficiency anaemia \\
\hline 18 & $0 \cdot 3$ & $2 \cdot 0$ & & Oesophageal varices \\
\hline 19 & 0.5 & 0.6 & & Myocardial infarction (on anticoagulants) \\
\hline 20 & $1 \cdot 3$ & $1 \cdot 7$ & & Gastric erosions \\
\hline 21 & 0.5 & $0 \cdot 8$ & & Chronic gastric ulcer \\
\hline 22 & 0.8 & $4 \cdot 1$ & 0.4 & Chronic gastric ulcer \\
\hline 23 & 0.4 & 0.4 & & Pyrexia of unknown origin \\
\hline 24 & 0.7 & 0.5 & & Diabetes mellitus \\
\hline 25 & $0 \cdot 1$ & 0.5 & & Myocardial infarction (on anticoagulants) \\
\hline 26 & 0.6 & 0.6 & $6 \cdot 5$ & Iron-deficiency anaemia \\
\hline 27 & $0 \cdot 1$ & $1 \cdot 3$ & & Oesophageal varices \\
\hline Mean & 0.6 & 0.8 & $3 \cdot 3$ & \\
\hline S.D. & 0.4 & 0.9 & $3 \cdot 3$ & \\
\hline
\end{tabular}


TABLE II

RESULTS IN 18 PATIENTS BLEEDING DURING CONTROL PERIOD

\begin{tabular}{|c|c|c|c|}
\hline \multirow[t]{2}{*}{ Patient } & \multicolumn{2}{|c|}{ Mean Daily Faecal Blood Loss (ml.) } & \multirow[t]{2}{*}{ Diagnosis } \\
\hline & Control Period & Paracetamol & \\
\hline 1 & $5 \cdot 5$ & 0.3 & Chronic gastric ulcer \\
\hline 2 & 16.9 & 10.9 & Gastric erosions; myelofibrosis \\
\hline 3 & $26 \cdot 6$ & $6 \cdot 1$ & Ulcerative colitis \\
\hline 4 & $2 \cdot 7$ & $2 \cdot 0$ & Chronic gastric ulcer \\
\hline 5 & 3.6 & 3.6 & Hypertension; gastric erosions \\
\hline 6 & $8 \cdot 7$ & $35 \cdot 9$ & Carcinoma of stomach \\
\hline 7 & $3 \cdot 2$ & 0.7 & Diverticulosis; gastric erosions \\
\hline 8 & $4 \cdot 0$ & $3 \cdot 1$ & Diabetes mellitus \\
\hline 9 & $10 \cdot 3$ & $11 \cdot 7$ & Post-gastrectomy gastritis \\
\hline 10 & $4 \cdot 5$ & 0.7 & Rheumatoid arthritis; gastric erosions \\
\hline 11 & $39 \cdot 8$ & 20.7 & Stomal ulcer \\
\hline 12 & $8 \cdot 8$ & $5 \cdot 2$ & Diabetes mellitus \\
\hline 13 & $2 \cdot 7$ & $2 \cdot \overline{7}$ & Myelofibrosis; thrombocytopenia \\
\hline 14 & $8 \cdot 4$ & $15 \cdot 3$ & Iron-deficiency anaemia; gastric erosions \\
\hline 15 & $2 \cdot 6$ & $1 \cdot 8$ & Hypoplastic anaemia \\
\hline 16 & 1.9 & $5 \cdot 9$ & Oesophageal varices \\
\hline 17 & $3 \cdot 2$ & $2 \cdot 1$ & Chronic duodenal ulcer \\
\hline 18 & 9.6 & $32 \cdot 7$ & Hereditary telangiectasia \\
\hline Mean & $9 \cdot 1$ & 9.0 & \\
\hline S.D. & $9 \cdot 8$ & 10.8 & \\
\hline
\end{tabular}

TABLE III

RESULTS OF CHEMICAL OCCULT BLOOD TESTING

Cr ${ }^{51}$ Labelling Method

\begin{tabular}{|c|c|c|c|c|c|}
\hline \multicolumn{3}{|c|}{ Haematest } & \multicolumn{3}{|l|}{ Occultest } \\
\hline Positive & Total & $\%$ Positive & Positive & Total & $\%$ Positive \\
\hline $\begin{array}{l}39 \\
12 \\
15\end{array}$ & $\begin{array}{r}102 \\
25 \\
29\end{array}$ & $\begin{array}{l}38 \cdot 2 \\
48 \\
51 \cdot 7\end{array}$ & $\begin{array}{l}95 \\
23 \\
25\end{array}$ & $\begin{array}{r}102 \\
25 \\
29\end{array}$ & $\begin{array}{l}93 \cdot 1 \\
92 \\
86 \cdot 2\end{array}$ \\
\hline
\end{tabular}

with Haematest tablets rose from $38 \%$ in specimens of faeces containing less than $2 \mathrm{ml}$. of blood to $52 \%$ in those containing more than $5 \mathrm{ml}$. of blood.

\section{DISCUSSION}

$\mathrm{N}$-acetyl-p-aminophenol has been given the generic name paracetamol. It is unrelated to aspirin, codeine, or amidopyrine and is the active metabolite of both acetanilide and phenacetin, but is free from their toxic metabolites, aniline and p-phenetidine. It is in common use as an analgesic and is often substituted for aspirin in the belief that it does not cause gastrointestinal bleeding in patients with peptic ucleration, blood dyscrasias, or on anticoagulant therapy, but there is very little experimental basis as yet for this belief.

Alvarez and Summerskill (1958) found that paracetamol did not influence the stool occult blood content using a Gregersen benzidine test, and Sutherland (1959) performed the benzidine faecal occult blood test twice weekly on six patients with duodenal ulceration on $3 \mathrm{~g}$. of paracetamol daily for three weeks and found only one positive sample. Wood et al. (1962) described a 40-year-old woman with rheumatoid arthritis who had a mean faecal blood loss of $4 \mathrm{ml}$. per day while on treatment with aspirin but whose faecal blood loss when on both hydroxyphenylbutazone and paracetamol was less than $1 \mathrm{ml}$. per day. Paracetamol did not have the topical irritant action of aspirin on the buccal mucous membranes of human subjects or on cat gastric mucosa (Roth, Valdes-Dapena, Pieses, and Buchman, 1963).

In this study, four of the 27 patients who were not bleeding in the control period had increased faecal blood loss when paracetamol was given. These four patients all had gastrointestinal lesions demonstrated: two had oesophageal varices and two had chronic gastric ulcer. There were three patients in whom faecal blood loss was decreased with paracetamol administration. In the second group of $\mathbf{1 8}$ patients already bleeding in the control period, four had increased faecal blood loss while paracetamol was being given whilst seven had decreased faecal blood loss. It is apparent that administration of paracetamol had no consistent effect on gastrointestinal blood loss. At times, blood loss increased and at other times it decreased so that there was no significant overall change in the mean daily faecal blood loss in these patients. This is to be contrasted with the 10 patients given aspirin in whom there was 
a significant overall increase in mean daily faecal blood loss.

The chemical occult blood tests in 150 specimens of faeces from these patients who were not on a restricted diet show both false positive and false negative results for Haematest tablets and oversensitivity for Occultest tablets. These results confirm the findings of Goldman, Paver, and Corbett (1964) who obtained $33 \%$ positive and $94 \%$ positive reactions for Haematest and Occultest tablets respectively in 107 patients without a known gastrointestinal lesion on an unrestricted diet.

\section{SUMMARY}

Faecal blood loss was measured in 45 hospital in-patients whose red cells had been labelled with $\mathrm{Cr}^{51}$. When paracetamol was given there was no significant increase in mean daily faecal blood loss in 27 patients who were not bleeding in the control period or in 18 patients who were bleeding in the control period. However, when 10 of these patients were given aspirin, there was a significant increase in mean daily faecal blood loss.

We wish to thank the honorary physicians of Royal Prince Alfred Hospital for permission to study patients under their care. We are indebted to Dr. J. McRae, Dr. H. Kronenberg, and Mr. John Maloney for their helpful advice. We would like to thank Sister V. Fagan and Sister B. Gibson for their assistance. Paracetamol was generously supplied as Panadol by Winthrop Laboratories.

\section{REFERENCES}

Alvarez, A. S., and Summerskill, W. H. J. (1958). Gastrointestinal haemorrhage and salicylates. Lancet, 2, 920-925.

Bannerman, R. M. (1957). Measurement of gastrointestinal bleeding using radioactive chromium. Brit. med. J., 2, 1032-1034.

Batterman, R. C., and Grossman, A. J. (1955). Analgesic effectiveness and safety of N-acetyl-para-aminophenol. Fed. Proc., 14, 316-317.
Cameron, A. D. (1960). Gastrointestinal blood loss measured by radioactive chromium. Gut, 1, 177.

Cornely, D. A., and Ritter, J. A. (1956). N-acetyl-p-aminophenol (Tylenol Elixir) as a pediatric antipyretic-analgesic. J. Amer. med. Ass., 160, 1219-1221.

Ebaugh, F. G. Jr., Emerson, C. P., and Ross, J. F. (1953). The use of radioactive chromium ${ }^{51}$ as an erythrocyte tagging agent for the determination of red cell survival in vivo. J. clin. Invest., 32, 1260-1276.

Goldman, P., Paver, W. K. A., and Corbett, W. H. (1964). The detection of occult blood in faeces. Med. J. Aust., 1, 755.

Grossman, M. I., Matsumoto, K. K., and Lichter, R. J. (1961). Fecal blood loss produced by oral and intravenous administration of various salicylates. Gastroenterology, 40, 383-388.

Holt, P. R. (1960). Measurement of gastrointestinal blood loss in subjects taking aspirin. J. Lab. clin. Med., 56, 717-726.

Jones, N. C. H. (1958). Measurement of red-cell loss from gastrointestinal tract, using radioactive chromium. Brit. med. J., $1,493-496$

Lange, H. F. (1957). Salicylates and gastric hemorrhage. I. Occult bleeding. Gastroenterology, 33, 770-777.

Leonards, J. R. (1962). Aspirin and blood loss from the gastrointestinal tract. Fed. Proc., 21, 452.

Matsumoto, K. K., and Grossman, M. I. (1959). Quantitative measurement of gastrointestinal blood loss during ingestion of aspirin. Proc. Soc. exp. Biol. (N.Y.), 102, 517-519.

Newell, J. E. (1960). Quantitative chemical assay of feces. Amer. J. clin. Path., 34, 189-190.

Newton, D. R. L., Tanner, J. M. (1956). N-acetyl-para-aminophenol as an analgesic: a controlled clinical trial using the method of sequential analysis. Brit. med. J., 2, 1096-1099.

Owen, C. A. Jr., Bollman, J. L., and Grindlay, J. H. (1954). Radiochromium-labeled erythrocytes for the detection of gastrointestinal hemorrhage. J. Lab. clin. Med., 44, 238-245.

Pierson, R. N. Jr., Holt, P. R., Watson, R. M., and Keating, R. P. (1961). Aspirin and gastrointestinal bleeding. Chromate ${ }^{51}$ blood loss studies. Amer. J. Med., 31, 259-265.

Read, R. C. (1954). Studies of red-cell volume and turnover using radiochromium. New Engl. J. Med., 250, 1021-1027.

Roth, J. L. A., Valdes-Dapena, A., Pieses, P., and Buchman, E. (1963). Topical action of salicylates in gastrointestinal erosion and hemorrhage. Gastroenterology, 44, 146-158.

Scott, J. T., Porter, I. H., Lewis, S. M., and Dixon, A. St. J. (1961). Studies of gastrointestinal bleeding caused by corticosteroids, salicylates, and other analgesics. Ouart. J. Med., 30, 167-188.

Stubbé, L. T. F. L., Pietersen, J. H., and Van Heulen, C. (1962). Aspirin preparations and their noxious effect on the gastrointestinal tract. Brit. med. J., 1, 675-680.

Sutherland, J. M. (1959). A report of some therapeutic trials. Med. J. Aust., 2, 470-474.

Watson, R. M., and Pierson, R. M. (1960). $\mathrm{Cr}^{51}$ assay of gastrointestinal blood loss in subjects taking salicylates. Fed. Proc., 19, 191.

Wood, P. H. N., Harvey-Smith, E. A., and Dixon, A. St. J. (1962). Salicylates and gastrointestinal bleeding. Brit. med.J., 1, 669. 